\title{
Indwelling without the Indwelling Holy Spirit: A Critique of Ray Yeo's Modified Account
}

\author{
Kimberley Kroll \\ University of St Andrews
}

\begin{abstract}
In 2014, Ray Yeo published a modified account of the Spirit's indwelling in "Towards a Model of the Indwelling: A Conversation with Jonathan Edwards and William Alston." Yeo utilizes a conglomerate of Two-Minds Christology and Spirit Christology to provide a metaphysical framework for his model which he believes offers a viable alternative to more traditional merger accounts like those of Edwards and Alston. After providing an overview of Yeo's objections to the merger accounts of Alston and Edwards, I will summarize Yeo's modified model. I will argue Yeo's emphasis on the humanity of Christ in lieu of a literal, internal, and direct union of the Holy Spirit and the human person cannot alleviate the core metaphysical concerns which surface in all accounts of union between the divine and human. Yeo's misunderstanding of Two-Minds Christology leads him to deny the full humanity of Christ; a humanity upon which his entire account of the indwelling relies. Yeo's modified model will be shown unsuccessful as an account of the indwelling of the Holy Spirit even if one accepts both his conception of Two-Minds Christology and his conditions for indwelling.
\end{abstract}

\section{Introduction}

In "Towards a Model of Indwelling: A Conversation with Jonathan Edwards and William Alston," Ray Yeo (2014) articulates an account of the Holy Spirit's indwelling, qualifying his project as "a modest constructive proposal for an important aspect of the indwelling" (i.e., the psychological change within the individual believer). Following an explanation of Jonathan Edwards's account of infusion and William Alston's preferred model of the indwelling, Yeo points out what he takes to be the problems inherent in each account. His primary concern is both Edwards and Alston assume a literal indwelling of the third person of the Trinity (i.e., a direct merger of divinity and humanity). Though Edwards and Alston both take this sort of union as necessary to an account of indwelling, Yeo quickly dismisses it as "theologically and philosophically untenable" $(2014,217)$.

Yeo's main objection against a model of the Spirit's indwelling of the merging sort Edwards and Alston hold is that the human mind cannot bear the psychological

Journal of Analytic Theology, Vol. 7, June 2019

10.12978/jat.2019-7.100824101711

(C) 2019 Kimberley Kroll • (C) 2019 Journal of Analytic Theology 
states of the divine mind. Yeo draws this conclusion because he understands the divine mind as necessarily trinitarian and perichoretic. Yeo provides what he sees as a possible solution to the unavoidable and incommunicable divide between the psychological structures of the human and divine mind. The human mind of Christ takes the role of mediating the divine thought-life to other human minds. The role of the Spirit in this model is to act as the vehicle for the "immanent divine psychological life within the Godhead but only as incarnated in the human psychological life of Christ" (Yeo 2014, 224). On Yeo's account, to speak of the indwelling is to speak of the Spirit's assistance, once removed, in the communication of the contents of the human mind of Christ to the minds of human persons. Therefore, the direct union of the Edwardian and Alstonian type becomes an indirect union for Yeo; the human person is put in new relationship with the human mind of Christ, not the Godhead proper.

In this paper, I will summarize Yeo's understanding of both the Alstonian and Edwardian accounts of the indwelling and the problems Yeo finds worrisome with those accounts. I will present Yeo's modified model of the indwelling and what he foresees as a possible objection to this model. I will show that Yeo's emphasis on the humanity of Christ in lieu of a literal, internal, and direct union of the Holy Spirit and the human person, cannot alleviate the core metaphysical concerns that surface in all accounts of union between the divine and human. Though Yeo's concern regarding the role of the humanity of Christ is relevant in articulating a robust account of the indwelling, he privileges the humanity of Christ over and above the Spirit, which runs contrary to the traditional understandings of indwelling. Yeo's account is fundamentally an indwelling without the Spirit of God indwelling.

Yeo entitles his model "a modified account" of indwelling, believing it to be a synthesis of the Alstonian and Edwardian models. This, however, is not the case as he changes and omits desiderata which Alston and Edwards find necessary for a theologically sound account of the indwelling. Yeo redefines indwelling to allow the divine and human participants to maintain necessary theological and metaphysical distinctions by way of the often-dismissed role of Christ's humanity. However, how Yeo understands and utilizes Two-Minds Christology undermines the very humanity of Christ that he seeks to promote. Given Yeo's own conditions for an account of indwelling (no direct relation, differing structures of mind, and the primacy of Christ's humanity as content and mediator), his model still faces considerable metaphysical lacunae which are no less problematic than those found in either Alston's or Edwards's merger accounts.

\section{The Starting Point: Uniqueness and Language}

The first problem one stumbles upon when attempting to construct an account of the indwelling of the Holy Spirit is the unique and, in a sense, real way (somehow in us!) that transcendence is made immanent and the immanent is made transcendent. ${ }^{1}$

1 The Christian tradition has sought to understand and hold in tension the transcendence and immanence of God. This is present in creedal development and the growing specifications as to how to 
Immediately, one's mind wanders to the person of Christ-God in flesh. It seems plausible that the indwelling relation of the Holy Spirit is akin to the relation of the hypostatic union. In the hypostatic union there is a direct and unmediated relation where two metaphysically distinct kinds, humanity and divinity, in no way comingle yet can be said to interpenetrate in a way referred to as "union" and localized in a single person. ${ }^{2}$ Though the person of Jesus Christ might be evidence that this sort of "unionizing without compromising" relation is possible between divinity and humanity, it does not illumine the inner workings of the similar (though not identical) relation between divinity and humanity by way of the Spirit's indwelling a human person. There are two important distinctions to remember when demarcating the uniqueness of the indwelling relation. First, Christ is one person united in humanity and divinity, while the indwelling is not merely a union of divinity and humanity, but a union of persons-divine and human. ${ }^{3}$ Second, the indwelt person is never a divine person and therefore does not relate to the Godhead in the same way as the divine person Jesus Christ. ${ }^{4}$

The second problem in the literature addressing indwelling is confusion regarding the definition and range of terms associated with it. For the Church Fathers, it was a given that God and humans were of different kinds. A human person is never unified with God in such a way that he would be God or be one substance with God. What was up for discussion was what it means to be "deified" with the condition that one never become something other than human. ${ }^{5}$ If one wants to present a clear account of the Spirit's indwelling, he must define terms of union, explain the nature of the relation of said union, determine what it is that is being unified, and determine what if anything is transferable through this union. After these terms are clarified, then one can attempt to construct a model as to how this indwelling relation works and is experienced. In Yeo's presentation of the three models, these words and concepts are never defined clearly. Therefore, in the overview of the models, the terms will retain their ambiguity.

\section{Yeo's Objections against Merger Models}

understand the person of Christ by way of distinction. Though this is most clearly seen in Chalcedon

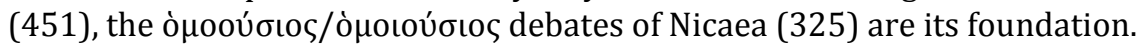

${ }^{2}$ See the Athanasian Creed: "Although he is God and Man, yet he is not two, but one Christ. One, not by conversion of the Godhead into flesh; but by assumption of the Manhood into God. One altogether; not by confusion of Substance; but by unity of Person. For as the reasonable soul and flesh is one man; so God and Man is one Christ" (Schaff 1877, 69).

3 The use of the term merely should not be understood to minimize the complexities and grandeur of the hypostatic union.

${ }^{4}$ The person of Jesus is identical to God; however it is that the divine person of the Son relates to the Godhead proper while on earth, it is not the same relation that the human person has with the Godhead. For instance, the indwelt believer can never proclaim, as Jesus did in his response to Philip in the Gospel of John, "Whoever has seen me has seen the Father. How can you say, 'Show us the Father'? Do you not believe that I am in the Father and the Father is in me" (John 14:8-10).

${ }^{5}$ The concept of being deified was so deeply ingrained within the minds of the Fathers that it was utilized to argue for the divinity of Christ and, subsequently, the divinity of the Spirit. For a discussion of this point see Russell 2006. 
Alston and Edwards's models both assume a sort of merger between the Spirit of God and the regenerate human person. How this merger is to be understood is not completely clear, but Yeo's discussion of the metaphysical obstacles present in both models creates doubt as to their probability. Yeo believes both models do not take seriously the transcendence of God or the humanity of Christ. Because of this trivialization, Alston's model lacks a metaphysical foundation and Edwards's model of infusion lends itself to the heresy of monism.

\section{Alston's Partial-Life Sharing Model}

In his essay, "The Indwelling of the Holy Spirit," William Alston (1989a) provides three models of the indwelling, the fiat model, the interpersonal model, and the partial sharing model. He is concerned with understanding the level of intimacy involved in the process of (moral) sanctification as well as which agent is responsible for acting in particular events (e.g., where does God's agency start and the human's end, and/or how does agency function at a level of cooperation between the divine and human persons). Alston believes his first two models are inadequate accounts of indwelling because they are unable to explain the internal nature of the relationship. Therefore, he offers a third model, the partial-life sharing model, which combines and modifies the fiat and interpersonal models.

In the fiat model, God implants a new disposition in the believer. This should be understood as something akin to the divine action of creation. On the fiat model God creates ex nihilo. The human person is, in an instance, given a newly created disposition with new tendencies. Alston explains, "it is just as if God had originally created [this new person], the difference lying only in the context within which the divine activity takes place" (1989a, 223).

Alston is dissatisfied with this model because it is not personal enough. God has created human persons; God would, thus, interact with humans in a way appropriate for human relations between persons and not act upon a person as he does with other nonpersonal aspects of creation. ${ }^{6}$ Particularly, Alston is concerned that to accept the fiat model is to remove the agency of the human person. Other than being able to posit an answer for Alston's initial question of how moral transformation might occur in the believer, the fiat model, without modification, does not satisfy his desire for an internal and personal account of the indwelling.

The interpersonal model is analogous to relationships among human persons. God calls, and the human person responds. There is interchange between God and the human person such that, over time, the human person's thoughts, motivations, and dispositions gradually change to be more like the person with whom she is in relationship, in this case, God. The payoff of this model is that it takes account of

\footnotetext{
${ }^{6}$ It seems that God does, at least occasionally, work (or at least it is recorded) in so-called impersonal ways. See Numbers 12:24-27, Judges 6:24, 14:19; 1 Sam 16:13-14. Pentecost itself appears to be a wild act lacking personal intimacy as understood in terms of human interpersonal relations (Acts 2:14). It seems the indwelling alone requires this sort of personal internality.
} 
humans as persons. Yet, the model is still unsatisfactory for Alston, in that it does not account for the way in which the biblical text implies a unique sort of presence of the Third Person in the relationship of indwelling. Further, like the fiat model, it does not explain the internal nature of the indwelling.

Alston's partial-life sharing model incorporates modified versions of the fiat and interpersonal models, yet it accounts for the intimate internality of the indwelling. This sort of indwelling relationship is required, according to Alston, because the biblical account maintains a distinction between the omni- and indwelling presence of the Spirit with believers. This unique indwelling presence happens by way of "literal merging or mutual interpenetration of the life of the individual and the divine" in which God shares Godself with a human person (1989, 246). Psychological content that, in a sense, is known and experienced of God as God knows and experiences it, is shared with the indwelt human person. ${ }^{7}$ Thus, Alston's partial-sharing model is a sharing that is both cognitive and conative. God is more present to the individual through a literal indwelling because immediate psychological access to the mind of God (to the extent of which man's mind is capable) is somehow experienced as internal to the human subject. The thoughts of God are experienced by the individual in a way similar to the way she experiences her own thoughts but remain distinct. What Alston believes is needed to give an adequate account for sanctification wrought through the indwelling of the Spirit, is that the indwelling be understood as not only internal but direct. The Spirit must not only be part of the act or action of indwelling, but the content (God himself) of it.

Yeo mentions two philosophical objections to Alston's partial-life sharing model. The first is that Alston does not account for the complexity of psychological states omitting a discussion of how one subject, God, might be able to share in the indexical thought-life of another. To fend off this objection, he believes Alston can posit something like omni-subjectivity ${ }^{8}$ as an attribute of God. ${ }^{9}$ Nevertheless, for Yeo, the real problem in Alston's account surfaces when one thinks of the sharing relation in the other direction (i.e., how it is that God shares of himself with the human person). The second objection is that a human mind cannot, in any ontological sense, bear the psychological states of God because God's psychological states are necessarily trinitarian and perichoretic in nature. Yeo writes:

The psychological elements of the Holy Spirit as a divine and triune being bear a kind of inherent trinitarian and perichoretic psychological structure that is so dissimilar to non-triune and non-divine beings like us that it is difficult to see how the psychological, metaphysical and ontological chasm between God and humanity can be crossed to allow

\footnotetext{
${ }^{7}$ Alston explains, "our participation in the divine life will consist of our attaining a knowledge of God as He is in Himself and a love of God for His own sake... as are enabled by sanctifying grace to enjoy the kind of knowledge and love of God enjoyed by God Himself" (1989a, 244).

${ }^{8}$ For a defense of omni-subjectivity see Zagzebaski 2016.

${ }^{9}$ First, this is still a problem for one who allows for omnisubjectivity. Second, though Alston does not spend time in his essay discussing how God knows the human psychological states, this is most likely due to his understanding of God's way of knowing. Whether Alston would need to accept something like omnisubjectivity on his understanding of God's knowledge is questionable. See Alston 1989b.
} 
for a direct and literal partial merging of psychological lives (2014, 218).

For Yeo, even if the number and kind of divine psychological states were qualified in some way such that they become sharable with a human mind, each divine psychological state would no longer maintain its trinitarian structure, having been abstracted from its trinitarian and perichoretic context. ${ }^{10}$ If this were to occur, the psychological states could no longer be considered divine, and the partial-life sharing model would no longer be able to do the sort of work Alston requires of it. There would thus be no way to salvage Alston's partial-life sharing model because a minimal direct merger of minds is not possible.

\section{Edwards's Model of Infusion}

The Edwardian corpus is large and the role of the Spirit in the life of the believer is fundamental to Edwards's understanding of all that pertains to life in God. Therefore, the bulk of his work, even when not focused on an account of the Spirit's indwelling relationship with the believer, mentions or implies certain concepts related to this relationship. Edwards believes the indwelling of the Spirit is something unique to believers - a direct relationship between a human person and a divine person, in which the Spirit is the literal content (equated with both grace and love) infused into the believer upon conversion. Once indwelt, the believer has a spiritual nature. It seems that for Edwards (as per Yeo's construal) a model of the indwelling must (1) be an infusion of the Spirit himself, (2) be internal to the human person which is distinct from God's general acting in the cosmos, and (3) transform the human person so that he is more fit to participate in and manifest God's glory. What Edwards's construction seems to lack, which Alston's model provides, is the deeply personal nature of this indwelling.

Yeo presents the Edwardian model of the indwelling of the Spirit in Edwards's terms, utilizing the language of infusion, principle of action, spiritual nature, etc. The Spirit is the grace or divine love infused into the believer as a "new and qualitatively distinct supernatural" principle of action which "exerts a kind of inhering and abiding influence within the subject such that it becomes an integral aspect of the individual and the very nature of the individual" (Yeo 2014, 210-11). The Spirit, now residing in the individual as the immediate presence and vital principle of action, transforms the whole person by acting within the faculties and dispositions of the regenerate believer. The initiation of this new indwelling relationship has necessarily introduced that which is unavailable to the natural human person-the Holy Spirit as indwelling presence. Like Alston's fiat model, the human person has a new state of being. In contrast to Alston's fiat model, it is not a newly created disposition put in the human but the Holy Spirit who is the new disposition. Though the Spirit may act through the

${ }^{10}$ Yeo does not clarify what a trinitarian and perichoretic psychological structure is. Further, it is unclear why one should assume that mind is something other than a natural kind (i.e., why assume that divine mind is necessarily disanalogous and incompatible with human mind?). 
means of a human person's natural faculties, for Edwards, God must remain the first cause of divine effects manifested in the person. The divine presence of the Spirit produces within the human person a new divine sense of holiness and delight in that holiness. Human persons indwelt by the Holy Spirit experience qualitatively distinct psychological states from the natural mind because of the presence of the infused Spirit. It is as if all that is created and present in the cosmos is perceived as having a new qualitative property of holiness which the regenerate has been given access to. ${ }^{11}$ However, according to Yeo, Edwards does not explain how the infusion of the Spirit as divine principle works, uniquely, within the individual to transform him. Therefore, Edwards's model is considered underdeveloped.

Yeo argues that Edwards's model, like Alston's, faces the difficulty regarding how divine psychological states are shared with the human mind. On both models, a direct sharing of the divine mind is integral to the indwelling of the Holy Spirit. For Yeo, any direct sharing of the divine with the human fails due to his construal of the divine mind as necessarily trinitarian and perichoretic. But, Edwards's account, as per Yeo's reading, falters not only metaphysically but also theologically; the Edwardian account lends itself to heresy.

Yeo's first theological objection is that Edwards's model of the infusion of the divine Spirit entails a strong account of theosis which might lead to a form of monism where the divine and human substances merge. ${ }^{12}$ Edwards faces the accusation of monism because of his commitment to God's simplicity. If God is simple (i.e., without composition and wholly identical to "attributes" ascribed to him) the infusion of the Spirit is an infusion of the divine essence..$^{13}$ If, on Edwards's model, referring to the divine person is to refer to the divine essence, the human person is infused with the divine essence. Yeo then goes further and assumes that if the Spirit as divine essence is infused, the account must then entail a fusion of the divine essence and the human person. On this understanding, what is communicated by means of the indwelling cannot be limited to "holiness" as one might understand Edwards attempting to defend. But, if a simple God does not have attributes because he necessarily is his attributes, attributes alone cannot be communicated via the indwelling. Instead, the holiness which Edwards believes is transferred and shared would be the literal essence of God. To avoid this conclusion, Edwards articulates a way in which "divine nature" (i.e., what is being partaken of by a human person in indwelling relationship

\footnotetext{
${ }^{11}$ One can understand this as a purity of mind which glimpses the sacredness of all creation. One experiences the blooming rose with a bit of insight into its true state as created in relation to the divine through and because of the Divine One within. This occurs because the Spirit is indwelling and providing access, understanding, and experience of creation which the natural man cannot seek out on his own. Ultimately, it is not just a human understanding herself relative to this new relation to God, but she now contemplates and experiences afresh how all of creation exists in relation to God.

12 The term "theosis," in current scholarship, is applied to a host of differing concepts related to Christianity, many of which cannot be understood to be a proper understanding of theosis. It is a caricature of theosis to think that it entails the merging of divine and human essences. This has led to confusion regarding how particular authors understand the term and apply it. See Lossky 1976, Olsen 2007, and Gavriluk 2009.

${ }^{13}$ Yeo relies on Oliver Crisp's understanding of Edwards's use of essence in relation to the persons of the Godhead. See Crisp 2010.
} 
with the Spirit) signifies yet is not equivalent to that divine essence. ${ }^{14}$ Yet, on Yeo's definition of simplicity, human persons infused with the Holy Spirit would share in the immanent trinitarian life. ${ }^{15}$

The second theological objection to the Edwardian model is that it marginalizes the role of Christ's humanity in participation and sanctification. According to Yeo, Edwards orders the human person's union with the Holy Spirit as logically prior and foundational to union with Christ which in some way derives from the former. Further, because Edwards appears to understand the language of Spirit of God, Holy Spirit, and Spirit of Christ as mapping on to the same referent, (i.e., the divine) a human person's union with the Spirit of Christ is the same thing as saying the human person is in union with the divine Son. ${ }^{16}$ On Yeo's understanding, the humanity of Christ no longer plays a role in either participation or sanctification wrought by way of the infused Spirit. The worry seems to be that the humanity of Christ is outflanked. For Yeo, the sanctification of Christ's humanity is what is efficacious in the human person's sanctification and Christ's humanity is that which is actualized in the human person by way of the indwelling. In Yeo's parsing of Edwards, Christ's life, death, resurrection, and ascension become nothing more than pre-conditions for the gift of the Spirit.

\section{What's the Indwelling of the Holy Spirit without the Holy Spirit Indwelling?}

Yeo constructs a modified account of the indwelling utilizing Alston's structure and the language of Edwards. Yeo believes the humanity (specifically, the human mind) of Christ can bridge the metaphysical lacuna of the doctrine. What is necessary on both the Edwardian and Alstonian models-a literal direct relationship with the Third Person via the indwelling-is omitted from Yeo's model and he must find an alternate account for the unique relationship. For Yeo, the Spirit does not indwell the human person in any real sense. Instead, Yeo explains, "for God to infuse his love within our hearts is for the resurrected and living incarnate Christ to partially share his ongoing human loving disposition with us by means of the Holy Spirit" (2014, 225). Drawing a distinction between the act of infusion and the content infused, Yeo understands the partial sharing of Alston's model to be contained within the human

\footnotetext{
${ }^{14}$ See Edwards 2004, 1263.

${ }^{15}$ See Cotnoir 2017 for six versions of simplicity. A weaker more nuanced version of simplicity might be able to bear Edwards's account. Further, one wonders if this concern is valid. It seems that even if one dismisses the simplicity doctrine, a literal infusion of the divine person into a human person faces the same problem of monism, which means it is present in Alston's account as well even though he does not hold to a doctrine of simplicity.

${ }^{16}$ Alston clearly states that he will use these terms equivocally because the biblical text seems to do so. Romans Chapter 8 provides a keen example of the ambiguity and fluidity of the terms (1989a, 226). For some reason Yeo sees this as a problem for Edwards, but not Alston. The real problem seems to be Yeo's assumption that Edwards equates the Spirit of Christ with the divine Son which somehow minimalizes his full humanity. For this to be suspect, one would have to hold there to be an essential distinction in the person of the Son and the person of Jesus Christ.
} 
mind of Christ. This condition "exclude[s] divine psychological states or dispositions that are constituted by elements that cannot be shared with another human subject. . . [such as] conscious subjectivity and indexical representational content" $(2014,224)$. Therefore, Yeo modifies the concept of indwelling in two important ways. The first is that the indwelling relationship is not a union between the Spirit and human person but between the humanity of Christ and the human person. Second, what is shared by way of that relationship is not the divine mind but the human mind of Christ:

Therefore, on this modification, humanity does not share directly in the immanent divine psychological life within the Godhead but only as it is incarnated in the human psychological life of Christ. The human life of Christ thus serves as a mediatory for man's union and participation in the life of God. Humanity is only indirectly united with the psychological life of God via being directly united with the human mind of Christ $(2014,224)$.

Not only do these qualifications seem to alleviate Yeo's account of the metaphysical problem of ontological "distance" involved in divine and human sharing, but they also reinstate the humanity of Christ in its rightful place of prominence as the cause and means of union which sanctifies the believer. What remains to be considered is whether sacrificing the traditional understanding of the Spirit as within the believer can provide an adequate account of the doctrine that is both metaphysically and theologically tenable.

\section{Yeo's a-Indwelling}

In Yeo's model, the partial human mind of Christ and not the Holy Spirit is what is infused into the believer to produce psychological transformation via "indwelling." In his model, Yeo claims: (1) Christ shares his human drive for union with God, (2) Christ's human unitive drive "opens" a new disposition to appreciate that which is aesthetically pleasing and good, (3) new epistemic access is provided through sharing in the mind of Christ, and (4) as Christ's human unitive drive matures within the human person he, in some borrowed fashion, shares in the inter-trinitarian life via (and just as) the human mind of Christ. Though Yeo makes use of Edwards's idea of the infusion of a loving disposition, this infused love is not the Spirit, but the goodseeing qualities and love towards God present in the human mind of Christ.

This human love, on Yeo's account, is not the robust virtuous love the Son has perfectly for the Father, but a germ of it. The unitive drive is like a seed which, over time, develops into a proper longing formed in the human person for the trinitarian divine life. To develop this point, Yeo uses the analogy of the beginnings and maturation of the human sex drive in a boy. To begin, the boy experiences only an urge which lacks representational content or clarity regarding the source or object of the urge. Over time, the boy understands what it is he desires and begins to grasp the good qualities of that which he desires. Yeo opts for the analogy of the sex drive 
instead of romantic love because he understands this drive as foundational to romantic love. He writes,

[T] hrough the development of a sex drive he has come to acquire novel powers of appreciation, perception and enjoyment of the ways in which they are good in a manner not possible before. These new powers of his psyche in turn motivate him towards union of life with members of that gender $(2014,226)$.

Without this sex drive, the boy, according to Yeo, could not appreciate certain beauties about the other. Ultimately, this understanding of how the infused disposition affects the mind it has been infused into is very similar to Edwards's account. This loving disposition of Christ matures through the human person's experiencing and acquiring representational content which transforms the mind and produces virtue with a divine quality.

Yeo believes his account of the indwelling is still, primarily, a work of the Spirit in that the Spirit mediates and maintains the presence of Christ; specifically, the Spirit acts as mediator between the human mind of Christ and other human minds. He writes,

[T] he Holy Spirit plays the crucial role of functioning as the divine vehicle through which the particular and localized human unitive drive of the living Christ is made universally and simultaneously present and available to all members of the body of Christ $(2014,228)$.

Yeo believes that he can explain how the Spirit indwells by distinguishing "the act of infusion and the content that is infused" $(2014,228)$. He agrees with Alston that the Spirit acts to break barriers between the divine and human persons full stop. But, what is shared is the unitive drive of the human mind of Christ, not the Spirit himself as in Edwards, and not the divine psychological states of the Godhead as in Alston. Yeo believes this modification to what is shared can avoid the problem of a merger which collapses necessary distinctions between divine and human kinds. There is a merger between the human person and the humanity of Christ but not an ontological merger with the divine. Yeo believes his account evades the problem of sharing divine and human psychological structures because divine psychological structures are not shared. Only the human psychological structures of Christ's human mind are shared. ${ }^{17}$ This shared content becomes an inhering disposition of a human person's cognitive system just as the Spirit himself becomes such on Edwards's account.

\footnotetext{
17 Yeo is working under the assumption, I believe, that the psychological dispositions (and their structure) of the human mind of Christ are accessible in the same way one human person can access another human person's mind. It seems that psychological dispositions are accessed and experienced just as one might be able to do with any another human person. Eleonore Stump uses the analogy of human mind reading in her account of mutual indwelling between God and human persons. However, she highlights more than once that the relation of the indwelling of the Spirit is of an "ontologically greater" sort than can occur in human mind reading $(2018,136)$. On her account, Christ's humanity plays a primary role in relating humanity to the divine, but the Spirit plays the primary role in
} 
In Yeo's model, Christ's human unitive drive is superhuman, due to its unique relation to the divine trinitarian nature via the hypostatic union. The Son alone will have a trinitarian-human drive (shared and rooted in the everlasting love the man Jesus, as the only Son, has for the Father) and "developed and shaped under the influence of his unique human participation in the intra-Trinitarian communion as the only Son" $(2014,231)$. This unitive drive comes into existence in the Incarnation and cannot be duplicated. Yeo explains, "it is a human disposition unique to the incarnate Son and is not naturally available to any created being who does not also enjoy the intra-Trinitarian communion as an uncreated person of the Trinity" (2014, 231). By extension and through the union of the natures in the hypostatic union, an indwelt person is brought into relationship with the immanent Trinity by way of the psychological states of the human Christ as mediated by the Spirit.

The major insight gained through Yeo's model is the attention given to the ongoing nature of Christ's work in sanctifying the believer (i.e., his continued priesthood-though Yeo does not describe it as such). Christ is not just the image one imitates, but he continues to be at work in the redemption of creation alongside the Father. ${ }^{18}$ To his credit, Yeo strives to incorporate the uniqueness of the Incarnation not just as Christ's manifestation on earth but in the larger cosmic schema. Christ's love for the Father, in his sanctified humanity, is maintained by the Spirit and perpetuates throughout eternity. If this loving relation is not upheld, there is no loving disposition for the Spirit to infuse into the believer nor would an already infused disposition of love in a regenerate person be able to be sustained by the Spirit. Christ's humanity is the immediate object of the union providing the "causal grounds" for sanctification $(2014,225)$. Christ plays the key role in the founding, sustaining, and bringing to fruition of all things.

Though I am mostly in agreement with this, I wonder why the Spirit must continue to maintain Christ's love for the Father after glorification; and, more simply, how any of this helps one to better grasp the doctrine of indwelling as attributed to Third Person. ${ }^{19}$ It seems that the indwelling is stripped of the Spirit and collapses into a work of Christ. There appears to be some sort of assumption that it is only the Son, by way of the flesh, who can have direct relation with humanity. Further, although positing more steps of mediation might give the appearance that the ontological gap between the divine and human has been pacified, it nevertheless remains. The indwelling of the Spirit is, crudely put, that final relation between the human person and God (no matter how many other steps of mediation might exist).

Yeo's overemphasis on the role and effect of Christ's humanity for the indwelling raises two problems. First, he constructs his model in such a way that it relies heavily on the language of minds, thereby committing him to a Two-Minds

mediating the divine to the human. Whether this ontologically richer relation is clearly developed in Stump so as to have explanatory power is uncertain.

18 See John 5:17-20; Rom 8:34-39; Hebrews 7:24-27, 8:1-2; John 2:1-2.

19 John 7:37-39,14:16-17, 25-26, 16:12-15; Rom 8:9-16, 1 Cor 6:19; Gal 3:3, 4:6; Ephesians 1:13-14, 4:30; 1 John 2:20-22, 27, 3:9, 4:12-14. These verses address the Spirit being in the believer. There are many others which describe the Spirit's ministry to the saints as an imitation of Christ's ministry; the Spirit's ministry will be both from within and without (in interplay). 
Christology.20 But a Two-Minds model of Christology cannot provide the metaphysical support Yeo desires, and so leaves his model no more metaphysically tenable than Alston and Edwards's models, which, truer to tradition, hold the Spirit to be in direct and immediate union with the human person. ${ }^{21}$ Second, Yeo's model is unable to account for how one shares not only in the human mind of Christ, but in the divine life of the Godhead (a weakness not present in either Alston or Edwards's models).

To resolve this, Yeo relies heavily on Two-Minds Christology to carry the metaphysical burden, claiming that the union of two minds in Christ not only allows for the human mind of Christ to be shared by way of the indwelling, but also provides a sort of mediated back door to the life of the Godhead such that the divine life can be shared vicariously in the same way the human mind of Christ shares in the divine life. The Spirit's place in this relation is "the indwelling means" of union $(2014,229)$. This dearth of the Spirit, who is understood as being merely the maintainer of the relation, is most starkly seen in both the limited content shared by way of the indwelling and the scarce intimacy between the Spirit and human person. To accommodate this deficit, the Spirit is said to maintain not only the relation between the minds of the human person and the human Christ, but also the love the human Christ has for the Father. Whether the Spirit is involved in this or not is far removed from the doctrine that the Spirit takes up residence in the believer.

Yeo's shift in focus from the problems of union between the divine and human persons in a human being indwelt by the Holy Spirit to the divine and human natures in the single person of Christ is infelicitous for two reasons. First, Two-Minds Christology cannot elucidate how the divine mind acts on or within the finite human mind. Second, as will be seen in the following sections, Yeo's explication and appropriation of this Christology to his model of indwelling diminishes the humanity of Christ in a way far beyond that of which he accuses Edwards. Yeo's model ends up necessitating a Christology that sounds and feels Nestorian but, at the heart, is a modern form of Eutychianism.

\section{Two-Minds Christology}

\footnotetext{
20 There might be other Christological models which could work with this sort of model. A retreat into a classical model of the hypostatic union (e.g., reduplication) will face the same problems as its derivative (Two-Minds). Physicalist or Compositional accounts are not primarily concerned with how the natures interact within the person of Christ. Thus, though possible, I do not see pursuing a different model of Christology to be a fruitful endeavor to salvage Yeo's model.

21 This seems to occur with Moses (Exodus 33:11), Samuel (1 Samuel 3:1-9), the prophets (Ezekiel 2:1-3; Hosea 1:10), Paul (2 Corinthians 2:1-6), Philip (Acts 8:29), Peter (Acts 10:19-20), and the church (Acts 13:2). There is some degree of mediation in these cases, but all are attributed to God or the Spirit and seem to facilitate something beyond human to human relations. Further, all things are mediated through the human body in some way, but whether a human person can be understood as something other than an embodied thing is debatable.
} 
Yeo's main objection to the metaphysical tenability of both Alston and Edwards's models - a human incapacity to bear trinitarian perichoretic psychological states, if it is a real problem for merger accounts of indwelling, remains a problem for Yeo.

A proper understanding of Two-Minds Christology includes the following premises:

(1) For Christ to be fully human, he must exemplify, without excess, all necessary human properties.

(2) For Christ to be fully divine, he must exemplify, without deficit, all necessary divine properties.

(3) Christ's full humanity entails he have a human mind.

(4) Christ's full divinity entails he have a divine mind.

(5) Christ's human mind is asymmetrically related to his divine mind.

Therefore, the single subject of Christ is both fully human and fully divine in that he contains both a human and divine mind, yet the human mind does not have access to divine properties of the divine mind which are (possibly) non-continuous or contradictory to properties of the human mind.

Two-Minds Christology cannot provide the metaphysical framework for Yeo's model of the indwelling. Yeo desires the human mind of Christ to have access to and to participate in the immanent Trinity in a way different than other human minds. As such, his model denies premises (1) and (3), and qualifies (5)..$^{22}$

The first premise requires that the humanity of Christ be "consubstantial with us according to the Manhood; in all things like unto us, without sin."23 Jesus Christ is fully human, not merely human, in the sense that his human nature is free from sin. ${ }^{24}$ Therefore, he may appear to present properties which are true of all human persons but not witnessed in any other human person. In other words, the more severe sin's effect on creation and particularly on human nature and its manifestations, the more extraordinary or unique certain properties of Christ may seem when contrasted with those of a human person conditioned by sin. However, any property instantiated in Christ's human nature must be possible of all human natures when sin is not present in that nature. Christ's humanity must be essentially of the same nature as any other human being. What is unique about Christ is not found in his natures, but instead in his person as the Son of God in flesh-fully divine and fully human-without either of those natures being compromised in any way.

Though Yeo wishes to position Christ's humanity at the center of his account, he ends up denying the first premise of the Christology he commits to. Yeo wants to

\footnotetext{
${ }^{22}$ Qualification of the fifth premise does not need to be expounded in the critique as it is a consequence of denying premises one and three. The denial of premises one and three is adequate for the disqualification of the model as a model of the indwelling of the Spirit. As will be shown, the denial of premises one and three makes it such that the phrase "human mind" refers to something other than a human mind.

${ }^{23}$ Chalcedonian Creed (451). See Schaff 1877, 62.

${ }^{24}$ For a discussion regarding Christ as having a fallen human nature, see McFarland 2010, 117-141. Though sin is traditionally understood as accidental to human nature, due to different understandings of soteriology, some think Christ must somehow (even if he is sinless) be understood as fallen.
} 
be able to attribute properties to Christ's humanity which are not available to all human persons. In his model, these properties facilitate the relation between the divine mind and Christ's human mind and then further provide the relation between Christ's human mind and other human minds via indwelling. In Yeo's model, Christ, in his human nature with a human mind, instantiates properties that are inaccessible, in principle, to other human persons. It appears that Christ's human mind has unique properties such as the ability to bear and comprehend divine pericherotic trinitarian psychological states and the ability to reconfigure these states so as to make them accessible to other human minds. But, if Christ is to retain his full humanity, his human mind cannot have excess properties not available for instantiation by other human minds.

As a consequence, Yeo must deny premise three. According to Yeo, Christ's mind is in some way "superhuman" (Yeo 2014, 231). One might argue Christ's human mind is not modified as other human minds would be in their contingent state of fallenness. And because Christ's human mind is without sin, it is able to instantiate properties that appear to be superhuman. But, this cannot be the case. It seems that either Christ's human mind, like all other human minds, should fail to have the capacity to bear trinitarian psychological states, or one must understand each human mind, being of the same sort as the human mind of Christ, to have latent capacities for something like trinitarian perichoretic-type psychological states. ${ }^{25}$ If this were the case, there would be no need for the divine psychological states to be mediated through the human mind of Christ; the Spirit could directly facilitate (just as in the relation between the human and divine minds of Christ) ${ }^{26}$ the sharing of divine psychological states without abstraction for or within the regenerate mind of a human person.

\section{Spirit of the Gaps}

\footnotetext{
${ }^{25}$ A possible objection to this statement might be that if any human nature were assumed by the divinity, then the mind associated with that human nature would have the capacity for something like trinitarian perichoretic-type psychological states. If this is the case, Christ would be the only person in whom the antecedent is satisfied (and so the only one in whom the latent capacity of the consequent is manifest). This objection initially seems to provide a way out for Yeo, but it has some strange consequences one might not want to open oneself up to. First, one would have to think that God created human persons with capacities essential to their being human, even though these capacities would never be instantiated by human persons, but only a divine person (i.e., when the divine person assumes the human nature). This seems odd. Second, one might worry that someone could label things we have thought unique and attributive only to the divine (e.g., the capacity for creating cosmos) as essential to humanity though never able for instantiation by humanity. Third, theologically, one would (1) need to commit to the necessity of an incarnation for union, and (2) allow for multiple incarnations; two things I am unsure Yeo would commit to, nor would I be willing to. I am grateful to one of the JAT editors for highlighting this possible objection.

${ }^{26}$ Yeo believes that this is not possible because the minds are united in one subject in Christ and there are two subjects involved in the indwelling. The problem with this is he does not approach the problem of indwelling through personhood. Thus, making this distinction is unhelpful to his argument. See Yeo 2014, 225 (footnote 35).
} 
Even if Yeo is able to show that Christ's human mind is not something other than truly human, he still needs to address issues more classically associated with the indwelling of the Spirit: (1) the communication of the divine life to human persons and (2) the dearth of the Spirit in his model. Yeo will try to address these problems with a single solution-a modified Spirit Christology. Spirit Christology, which stems from a robust pneumatology, holds that it is "the Spirit who is the point of contact between the divine hypostasis and the humanity of Jesus" (Habets 2016, 207-233). Because the person of the Son must act in accord with his human nature without a change in his divine nature, the Spirit acts to mediate between the human and divine natures in Jesus Christ such that any act of divinity witnessed in the person of Jesus Christ should be attributed to the Holy Spirit's action in him. Therefore, the Son is only indirectly related to his humanity. The Spirit plays a significant role in sustaining the human mind of Christ in its relation to the divine person of the Son. For Yeo, this sort of mediation continues in the glorified Christ.

The Spirit's working with the indwelt believer would be analogous to his intimate maintaining of the hypostatic union in Christ except it would be between the human person and the human mind of Christ. Therefore, the Spirit does double-duty. This double-duty or extended mediation would occur first, in the person of Jesus Christ, and second, in the regenerate person. In the first case, there is a person (Christ) with a divine nature that relates to a human nature by way of the Spirit's mediation. In the second case, there is a regenerate human person with a human nature which then relates to a second human nature (that belonging to Christ), by way of the Spirit's mediation. Therefore, the Spirit has a twice-over mediatorial role.

The problem remains as to how the human person is put into relation with the Godhead proper. Yeo seems to think that the regenerate's relation to the Godhead trickles down through the indirect relation of Christ's divine mind and his human mind (Spirit Christology), and then through the indirect relation between the human mind of Christ and the human person. But, an investigation into the indwelling relation is an investigation into what this final relation-by way of the Spirit's mediation-is in itself. This final relation between the human person and the Godhead, i.e., the Spirit in mediating relation with the human person is just the direct relation of the Spirit indwelling the human person.

This leaves two questions: (1) if the Spirit is the one in direct (immediate) relation between the divine Son in his divine nature and his assumed human nature, why shouldn't we understand the Spirit to be in direct (immediate) relation with the regenerate person and his human nature, and (2) if the Spirit maintains both distinction and fulfillment of natures between God the Son and Christ Incarnate, why could he not do the same in the regenerate human person? Regarding the former question, the content shared would be something of the divine nature. Regarding the latter question, divine content could be shared with a human person such that both the human nature and the divine nature remain distinct. Like the attempted utilization of Two-Minds Christology, Spirit Christology cannot provide a metaphysical structure for Christ's humanity to remain human and retain some sort of other than human properties. 


\section{Conclusion}

Ray Yeo's modified model of indwelling focuses on the transformation of the psychological structure of human persons to account for and understand the metaphysical and theological complexities of the indwelling relation between the Spirit of God and the human person. His concerns regarding a direct and immediate relation between the Holy Spirit and human person lead him to remove the Spirit both as a relatum in the relation and as the content of the relation. Instead, he opts for a model where the relation between Spirit and human person is an indirect form of union, mediated by the human mind of Christ-which is also its object. Yeo attempts to use a conglomerate of Two-Minds Christology and Spirit Christology to provide a Christ-centered foundation for his model, granting the Spirit a slightly modified, but more robust sort of facilitation. Though this move initially seems to evade classic theological (monism, divinization) and metaphysical (differing kinds) complexities related to union between the uncreated and the created, it has been shown to be unsuccessful and commensurate with a rejection of the indwelling relation which holds between the Spirit and the human person. This leaves Yeo with a problematic and possibly heretical understanding of the humanity of Christ, and a modified model absent the Spirit indwelling. 


\section{References}

Alston, William P. 1989a. "The Indwelling of the Holy Spirit." In Divine Nature and Human Language Essays in Philosophical Theology. Cornell University Press.

1989b. “Does God Have Beliefs?" In Divine Nature and Human Language Essays in Philosophical Theology. Cornell University Press.

Cotnoir, A.J. 2017. "Mutual Indwelling." Faith and Philosophy 34: 123-151. DOI: $10.5840 /$ faithphil201741179.

Crisp, Oliver. 2010. "Jonathan Edwards' Panentheism." In Edwards as Contemporary: Essays in Honor of Sang Hyun Lee, edited by Don Schweitzer. Peter Lang Publishing.

Edwards, Jonathan. 1999. "A Divine and Supernatural Light, Immediately Imparted to the Soul By the Spirit of God, Shown to Be Both a Scriptural, and Rational Doctrine (1734)." In The Sermons of Jonathan Edwards: A Reader, edited by Kimnach, Wilson H., Minkema, Kenneth P., and Sweeny, Douglas A. Yale University Press.

2004. “The 'Miscellanies,' 1153-1360." In The Works of Jonathan Edwards, Vol. 23: The "Miscellanies," 1153-1360, edited by Douglas A Sweeny. Yale University Press.

Gavriluk, Paul L. 2009. "The Retrieval of Deification: How a Once Despised Archaism Became an Ecumenical Desideratum." Modern Theology 25: 647-659. DOI: 10.1111/j.1468-0025.2009.01558.

Habets, Myk. 2016. "Spirit Christology: The Future of Christology?" In Third Article Theology: A Pneumatological Dogmatics, edited by Myk Habets. Fortress Press.

Lossky, Vladamir. 1976. In the Image and Likeness of God. Mowbrays.

McFarland, Ian. 2010. In Adam's Fall: A Meditation on the Christian Doctrine of Original Sin. Wiley-Blackwell.

Olsen, Roger E. 2007. "Deification in Contemporary Theology." Theology Today 64: 186-200. DOI: 10.1177/004057360706400205.

Russell, Norman. 2006. The Doctrine of Deification in the Greek Patristic Tradition, edited by Gillian Clark and Andrew Louth. Oxford University Press.

Schaff, Philip. 1877. The Creeds of Christendom with a History and Critical notes. Volume II. Harper Brothers. 
Stump, Eleonore. 2018. Atonement. Oxford University Press.

Yeo, Ray S. 2014. "Towards a Model of the Indwelling: A Conversation with Jonathan Edwards and William Alston." Journal of Analytic Theology 2: 210-237. DOI: 10.12978/jat.2014-1.170024240414a.

Zagzebaski, Linda. 2016. "Omnisubjectivity: Why It Is a Divine Attribute." Nova et Vetera, English Addition 14: 435-450. DOI: 10.1353/nov.2016.0030. 